\title{
REDUCING COMPETITION IN AGROFORESTRY BY PRUNING NATIVE TREES ${ }^{1}$
}

Maria Luiza Franceschi Nicodemo ${ }^{2 *}$, Paula Priscila Castiglioni ${ }^{3}$, José Ricardo Macedo Pezzopane ${ }^{2}$, Patrícia Tholon $^{4}$ and Antônio Aparecido Carpanezzi ${ }^{5}$

\footnotetext{
${ }^{1}$ Received on 23.05.2013 accepted for publication on 18.12.2015.

${ }^{2}$ Empresa Brasileira de Pesquisa Agropecuária, Centro de Pesquisa de Pecuária do Sudeste, São Carlos, SP - Brasil. E-mail: $<$ marialuiza.nicodemo@embrapa.br>and <jose.pezzopane@embrapa.br>.

${ }^{3}$ Universidade Camilo Castelo Branco, graduanda em Engenharia Ambiental, Descalvado, SP -Brasil. E-mail: <ppcastiglioni@hotmail.com>.

${ }^{4}$ Embrapa Pecuária Sudeste, São Carlos, SP - Brasil. E-mail: <patricia.tholon@embrapa.br>.

${ }_{5}^{5}$ Empresa Brasileira de Pesquisa Agropecuária, Centro Nacional de Pesquisa de Florestas, Laboratório de Ecologia, Colombo, PR - Brasil. E-mail: <antonio.carpanezzi@embrapa.br>.

*Corresponding author.
}

\begin{abstract}
The degree to which pruning helps reestablish balance in agroforestry was assessed in a system established in São Carlos, São Paulo, Brazil, in 2008. Seven native tree species were planted at a density of 600 trees/ha in five strips of three rows each, and annual crops were cultivated in the $17-\mathrm{m}$ crop strips between the tree strips. Competition was established after 35 months, decreasing the aboveground biomass production of corn planted close to the trees. An assessment of black oats in the dry season following tree pruning showed that the proximity of trees caused reductions in plant and panicle density, aboveground biomass production, number of grains per panicle and grain weight. Because pruning was not sufficient to maintain crop yields, tree thinning is recommended in order to minimize competition and restore conditions for adequate crop production.
\end{abstract}

Keywords: Crop-livestock-forestry integration; Silviculture; Sustainable

\section{REDUÇÃO DA COMPETIÇÃO EM AGROFLORESTA PELA DESRAMA DE ARVORES NATIVAS}

\begin{abstract}
RESUMO-Estudou-se o efeito da desrama no restabelecimento do equilibrio em sistema silviagrícola, implantado em São Carlos, SP em 2008. Sete espécies de árvores nativas, na densidade de 600 arvores/ha, foram plantadas em cinco faixas de três linhas, associadas a cultivos agrícolas anuais semeados nos $17 \mathrm{~m}$ entre essas faixas. A competição se estabeleceu aos 35 meses, reduzindo a produção de biomassa aérea do milho plantado próximo às árvores. Avaliação do cultivo de aveia-preta na estação seca subsequente a desrama mostrou que as árvores provocaram redução na densidade de plantas e de panículas, na produção de biomassa aérea, na quantidade de grãos por panícula e no peso dos grãos. A desrama das árvores não foi suficiente para controlar a queda da produção agrícola, justificando a indicação de desbaste para manutenção da produtividade do cultivo agrícola.
\end{abstract}

Palavras-chave: Integração lavoura-pecuária-floresta; Silvicultura; Sustentável 


\section{INTRODUCTION}

Planted forests are estimated to cover 264 million ha worldwide, and increased at a rate of 5 million ha/ year between 2000 and 2010 (FAO, 2010). Conventional forestry may not be attractive for small and mediumsized farmers due to the long investment periods required and the resulting limits on cash flow. When crops such as soybeans, corn, sorghum, and winter crops are planted simultaneously and/or sequentially in the land between lines of timber trees, they help defray the early costs of establishing forestry operations (RIBASKI et al., 2002) and can thus make it possible for smaller-scale farmers to practice forestry. These integrated crop-timber production systems now cover 1.6 million ha in Brazil, mostly in the midwestern and southern regions of the country. It has been estimated that 55 million ha in Brazil are suitable for integrated crop-pasture-timber (iLPF) systems (BALBINO et al., 2011).

Agroforestry systems established to date vary widely in their elements, tree density, spatial arrangement, and products. The most commonly used timber species in southeastern Brazil is eucalyptus, but farmers there are exploring alternatives, including some native species (RUSCHEL et al., 2003; CARPANEZZI et al., 2010).

Maintaining desired production levels of timber and crops in integrated systems requires monitoring the growth of both trees and crops, and management interventions such as pruning and thinning (JOSE et al., 2004). Pruning is a labor-intensive practice carried out to increase light levels in the understory and thereby boost the production of associated crops, and it provides a source of high-quality, knot-free wood. While the branches of Eucalyptus spp. are typically pruned up to $6 \mathrm{~m}$, most tropical timber species show sympodial growth (ENCINAS et al., 2005), with low, precocious branching, which complicates pruning. Thinning reduces competition for light, water, and nutrients both between individual trees and between trees and crops. Designers of agroforestry systems should note that early thinning of dense stands is justified when there is a market for the products it generates, such as firewood and wooden bracing for construction.

How long it takes before trees begin to interfere with crop growth depends on a variety of factors, including soil fertility, climate, tree architecture, and the degree to which the crops in question are shadetolerant. Understanding how the elements of an agroforestry system respond to management allows one to determine the most efficient strategies. The aim of this study was to assess the extent to which pruning helped reestablish the balance between trees and associated crops in an alley-cropping agroforestry system.

\section{MATERIALAND METHODS}

The study was carried out at Embrapa Pecuária Sudeste, in São Carlos, São Paulo state, Brazil (22 ${ }^{\circ} 1^{\text {' }}$ $\left.\mathrm{S} 47^{\circ} 53^{\prime} \mathrm{W}\right)$. The region's climate is classified as CwaAwa (KÖPPEN 1948), with an April-September dry season, a mean annual temperature of $21.2^{\circ} \mathrm{C}$, and mean annual relative humidity of $75.6 \%$. The area is largely flat, with slopes of $3-5 \%$, and mean elevation is $860 \mathrm{~m}$.

The study area was a Red-Yellow Latosol covered with Urochloa decumbens (syn. Brachiaria decumbens) (EMBRAPA, 1999). The agroforestry system was established in January 2008 as five strips of trees intercalated with annual crops. In each strip of trees, trees were planted in three lines that followed topographic contours and spaced $2.5 \times 2.5 \mathrm{~m}$, for a density of 600 trees/ha. The 17-m strips separating the tree strips were planted with annual crops. In the tree strips, the following timber species were planted in a random order along the central line: angico-branco (Anadenanthera colubrina); canafístula (Peltophorum dubium); ipêfelpudo (Zeyheria tuberculosa); jequitibá-branco (Cariniana estrellensis); and pau-jacaré (Piptadenia gonoacantha). To ensure that these species grew straight boles with a minimum of lower branches, the tree species mutambo (Guazuma ulmifolia) and capixingui (Croton floribundus) were planted in an alternating sequence in the two outer lines of each tree strip. Trees were fertilized in the first 18 months. Silvicultural treatments included removing leaf-cutter ants and keeping the area immediately around the seedlings free of grass.

Soils in the agricultural area were corrected starting at the establishment of the agroforestry system. Liming and fertilization were carried out based on annual soil analyses, and the following crops planted in succession. Forage sorghum (Sorghum bicolor) was planted in December 2007, fertilized with $500 \mathrm{~kg} / \mathrm{ha} \mathrm{8-28-16} \mathrm{NPK,}$ $20 \mathrm{~kg} /$ ha zinc sulfate, $3.3 \mathrm{t} /$ ha dolomitic limestone, and $400 \mathrm{~kg} / \mathrm{ha}$ 25-00-25 NPK, and harvested in April 2008. 
The sorghum was allowed resprout without further fertilization, cut in September 2008, and incorporated into the soil. Forage maize (Zea mays) was planted in November 2008, the soil amended with $1.5 \mathrm{t} /$ ha dolomitic limestone, $350 \mathrm{~kg} / \mathrm{ha} 8-28-46 \mathrm{NPK}+\mathrm{Zn}$, and $400 \mathrm{~kg} /$ ha $20-05-20 \mathrm{NPK}+0.6 \% \mathrm{~S}$, and the maize harvested in March 2009. Guandu-fava-larga beans (Cajanus cajan cv. Fava larga) were planted in March 2009, fertilized with $200 \mathrm{~kg} /$ ha simple superphosphate $+50 \mathrm{~kg} / \mathrm{ha}$ potassium chloride, and harvested in September 2009. Forage sorghum was planted in January 2010, fertilized with $300 \mathrm{~kg} / \mathrm{ha} \mathrm{10-20-20} \mathrm{NPK} \mathrm{and} 500 \mathrm{~kg} / \mathrm{ha} 20-05-20$ $\mathrm{NPK}+6 \% \mathrm{Zn}$, and harvested in May 2010. Forage maize was planted in November 2010, the soil amended with $2.5 \mathrm{t} /$ ha dolomitic limestone, $470 \mathrm{~kg} / \mathrm{ha} 10-1-10 \mathrm{NPK}$, and $500 \mathrm{~kg} / \mathrm{ha} 25-0-25 \mathrm{NPK}$, and the maize harvested in March 2011.

The forage crops were initially sampled in the entire study area, between tree strips. Starting in 2009, data were collected at three distances from the outermost trees in the tree strips: $2,4.75$, and $8.5 \mathrm{~m}$. Plants were cut $20 \mathrm{~cm}$ above ground level, weighed to determine their fresh matter yield, which was transformed to $t /$ ha. Samples of cut plants were oven-dried at $60^{\circ} \mathrm{C}$ until reaching a constant mass. Dry matter production/ha was calculated as the product of percent dry matter and fresh matter production.

In this experiment, control is the primary condition, of no competition, at the beginning of the experiment (baseline). Evaluations were made over time. We began in a situation of no competition, as indicated by dry matter production, stable along transects perpendicular to the tree strips. Competition was established 35 months after tree introduction, when dry matter production of forage maize was significantly different according to distance from the trees $(2 \mathrm{~m}=5846 \mathrm{~kg} / \mathrm{ha} \mathrm{c} ; 4.75$ $\mathrm{m}=8821 \mathrm{~kg} / \mathrm{ha} \mathrm{a} ; 8.5 \mathrm{~m}=7678 \mathrm{~kg} / \mathrm{ha} \mathrm{b}$; means followed by different letters differ significantly according to Tukey's test (5\% significance level)). Pruning was performed in order to restore crop production to acceptable levels. Mean tree height in May 2011 was $322 \pm 200$ (SD) cm for angico; $306 \pm 119 \mathrm{~cm}$ for canafístula; $651 \pm 119 \mathrm{~cm}$ for capixingui; $143 \pm 86 \mathrm{~cm}$ for ipê; 120 $\pm 96 \mathrm{~cm}$ for jequitibá; $668 \pm 138 \mathrm{~cm}$ for mutambo; and $398 \pm 198 \mathrm{~cm}$ for pau-jacaré. The capixingui and mutambo trees were pruned in November 2010. Pruning was carried out during the forage maize crop cycle, which meant it was not possible to measure its effects on forage production. The criteria used for pruning were that $50 \%$ of the green canopy be maintained and that branches be removed below the point at which the tree trunk had a diameter of $6-8 \mathrm{~cm}$.

The crop planted after pruning, black oats (Avena strigosa), was evaluated in detail. It was planted at a depth of $2-3 \mathrm{~cm}$, with $20 \mathrm{~cm}$ between lines, in April 2011. Seeding density was $60-65$ seeds per linear meter, for a density of $55 \mathrm{~kg} / \mathrm{ha}$ of seeds. The crop was fertilized with $300 \mathrm{~kg} /$ ha of $8-28-16$ NPK and $100 \mathrm{~kg} /$ ha of ammonium sulfate as topdressing. The oats were harvested in August 2011, once it was verified that the grains were filled. The oat crop was sampled between the tree strips and outside the tree strips, using a 1 x $1 \mathrm{~m}$ quadrat that included five lines of oats.

Eight transects outside the tree strips were assessed (the first line of oats outside each tree strip, and 3, $6,9,12,15,18$, and $21 \mathrm{~m}$ from that first line). In each transect oats were sampled and distances from the treeline measured. Oat samples were also collected between the strips of trees, at seven points on each of two transects per strip (Figure 1). Measurements were taken on the first line of oats, at the center of the crop strip, and at intermediate points between those two (two intermediate points to either side of the strip).

Before plants were cut, the number of plants $/ \mathrm{m}^{2}$ and panicles $/ \mathrm{m}^{2}$ were recorded. Oat samples were weighed when fresh and after they were oven dried at $60^{\circ} \mathrm{C}$ until they reached constant mass. Parallel to the area where the quadrats were sampled, 1 linear meter was sampled in order to evaluate the number of grains per panicle and the thousand grain weight. After panicles were sun-dried, the collected samples were threshed and placed in a sample blower for 2 minutes with a 5-cm opening. Immediately afterwards, $2 \mathrm{~g}$ of the sample were weighed and placed in the grain counter. Readings of photosynthetically active radiation (PAR) were taken in July 2011 with an LP-80 AccuPAR model ceptometer (Decagon). Readings were taken in four transects parallel to treeline at the two sites, at the same distances as the oat sampling. To calculate light incidence, readings were taken facing an $\mathrm{N}, \mathrm{S}, \mathrm{E}$, and $\mathrm{W}$ direction at each point. Water balance (THORNTHWAITE; MATHER, 1955) during the study period was calculated based on meteorological data from Embrapa Pecuária Sudeste.

Revista Árvore, Viçosa-MG, v.40, n.3, p.509-518, 2016

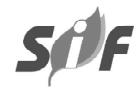


Soil samples were collected in July for humidity estimates using the gravimetric method, at $0-20 \mathrm{~cm}$. The samples were obtained in the same points as the oat samples, except that only two intermediate points in the internal transects (between tree strips) were taken. Samples were identified, dried in the oven at $105^{\circ} \mathrm{C}$ for $24 \mathrm{~h}$, up to constant weight. Water content was calculated from the difference between humid and dry weights.

The variables PAR, number of panicles $/ \mathrm{m}^{2}$, number of plants $/ \mathrm{m}^{2}$, thousand grain weight, number of grains/ panicle, and dry matter yield were evaluated with linear and quadratic regressions using the GLM procedure in SAS ${ }^{\circledR}$ software (SAS 9.1, SAS Institute, Cary, North Carolina, USA). The following effects were considered: site (outside the agroforestry system vs. between the tree strips) and distance from nearest trees. Radiation data calculated based on the predictive equation generated for PAR and distance from trees were used in the linear and quadratic regression analyses using the GLM procedure in SAS, to compare PAR with dry matter production. To analyze variance in PAR, the Mixed procedure in SAS was used for repeated measures (time of day). Distances, time of day, and their interaction (distances $\mathrm{x}$ time of day) were considered to be fixed effects in the model, and the replicates were considered to be random effects. For soil humidity only distances from the trees were considered. Multiple means were compared using Tukey's test at the 5\% significance level.

\section{RESULTS}

The experimental period coincided with an extreme drought (Figure 2) that was especially strong 60 days after the oats were planted, when soil water reached critical levels.

The proximity of trees changed the levels of photosynthetically active radiation (PAR) available to the black oats. Mean PAR levels in the first lines of oats were lower than at the other distances (Table 1). Mean PAR levels in the agroforestry system were higher between 11:45 and 12:50 than at other times of day $(\mathrm{P}<0.05)$.

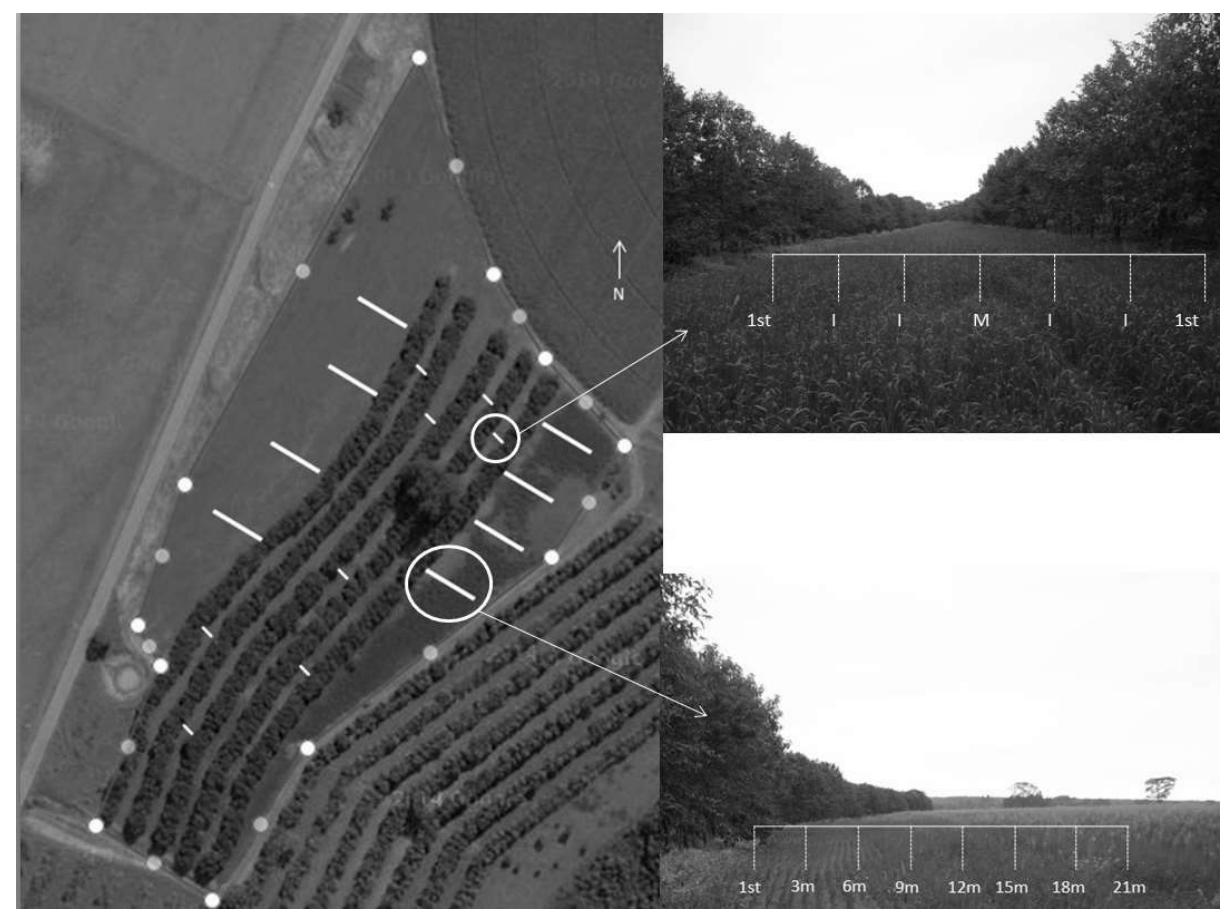

Figure 1 - Experimental area (surrounded by line with dots). Transects outside and inside tree strips, used for oats evaluation, are depicted (white lines).

Figura 1 - Área experimental (circundada por linha com pontos). Transectos dentro efor a das faixas de árvores, utilizadas na avaliação da aveia, estão indicados (linhas brancas).

Revista Árvore, Viçosa-MG, v.40, n.3, p.509-518, 2016 
Data on distance from trees (DIST) and PAR availability (expressed as the proportion of the point with the greatest light incidence, at $23 \mathrm{~m}$ from the trees, $\mathrm{Y})$ were fit to an exponential model: $\mathrm{Y}=98.74 *(1$-exp$0.2778 * \mathrm{DIST}) ; \mathrm{R}^{2}=0.70, \mathrm{P}<0.01$. The model showed

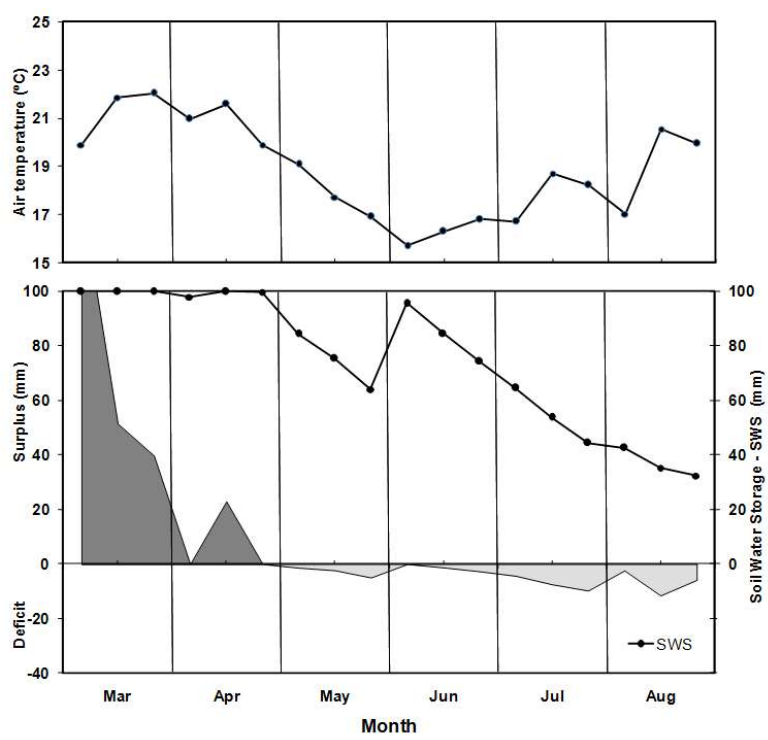

Figure 2 - Air temperature (above) and water balance (below) during the study period.

Figura 2 - Extrato do balanço hídrico climatológico durante o periodo experimental. that sites at least $10 \mathrm{~m}$ from the trees received $>90 \%$ of the maximum PAR obtained.

The relationship between proportional PAR incidence and the natural log of aboveground biomass production was linear (Figure 3 ). The conditions under

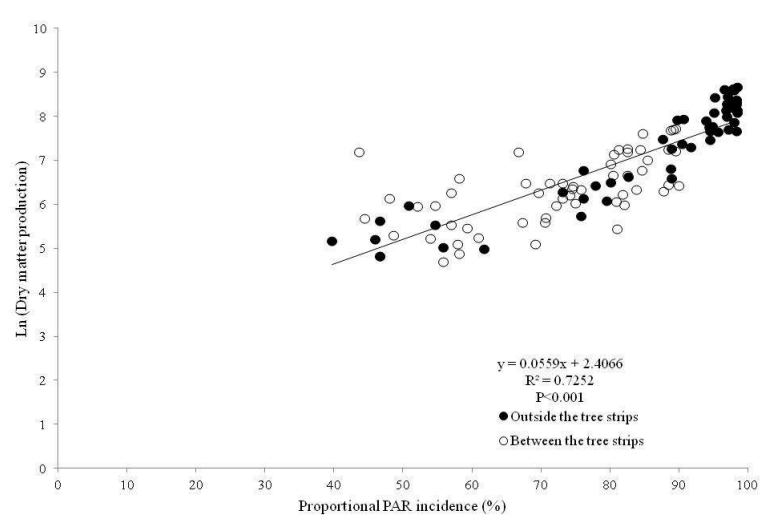

Figure 3 - Relative incidence of photosynthetically active radiation at different distances and $\ln$-transformed dry matter production of oats cultivated in an agroforestry system with native trees in São Carlos, São Paulo state, Brazil.

Figura 3 - Incidência relativa de radiação fotossinteticamente ativa em diferentes distâncias e produção de matéria seca (dados transformados em Ln) de aveia cultivada em sistema silviagrícola com árvores nativas em São Carlos, SP.

Table 1 - Mean incidence of photosynthetically active radiation (PAR; $\mu \mathrm{mol} / \mathrm{m}^{2} / \mathrm{s}$ ) at different times of day on $8 \mathrm{July} 2011$ and at different distances from trees in an agroforestry system (oats-trees) in São Carlos, São Paulo, Brazil.

Tabela 1 - Média de incidência de radiação fotossinteticamente ativa (RFA; $\left.\mu \mathrm{mol} / \mathrm{m}^{2} / \mathrm{s}\right)$ em diferentes distâncias e horários do dia 08/07/2011 no sistema silviagrícola de aveia e árvores nativas em São Carlos, SP.

\begin{tabular}{|c|c|c|c|c|c|c|}
\hline \multirow{2}{*}{$\begin{array}{l}\text { Distance } \\
\text { from trees }\end{array}$} & \multicolumn{5}{|c|}{ Time of day } & \multirow[t]{2}{*}{ Mean } \\
\hline & $9: 10$ & $11: 45$ & $12: 50$ & $14: 45$ & $16: 45$ & \\
\hline \multicolumn{7}{|c|}{ Site 1: Area outside the strip of trees } \\
\hline $2.14 \mathrm{~m}$ & $248.00 \mathrm{bc}$ & $476.25 \mathrm{ab}$ & $609.88 \mathrm{a}$ & $322.38 \mathrm{abc}$ & $36.88 \mathrm{c}$ & $338.68 \mathrm{~B}$ \\
\hline $5.14 \mathrm{~m}$ & $740.50 \mathrm{~b}$ & $1152.38 \mathrm{a}$ & $1056.50 \mathrm{a}$ & $391.50 \mathrm{c}$ & $52.25 \mathrm{~d}$ & $678.63 \mathrm{~A}$ \\
\hline $8.14 \mathrm{~m}$ & $786.75 \mathrm{~b}$ & $1155.50 \mathrm{a}$ & $1181.25 \mathrm{a}$ & $474.00 \mathrm{~b}$ & $60.00 \mathrm{c}$ & $731.50 \mathrm{~A}$ \\
\hline $11.14 \mathrm{~m}$ & $792.75 \mathrm{~b}$ & $1168.75 \mathrm{a}$ & $1186.63 \mathrm{a}$ & $721.50 \mathrm{~b}$ & $63.12 \mathrm{c}$ & $786.55 \mathrm{~A}$ \\
\hline $14.14 \mathrm{~m}$ & $787.00 \mathrm{~b}$ & $1168.75 \mathrm{a}$ & $1183.50 \mathrm{a}$ & $745.50 \mathrm{~b}$ & $66.12 \mathrm{c}$ & $790.18 \mathrm{~A}$ \\
\hline $17.14 \mathrm{~m}$ & $790.88 \mathrm{~b}$ & $1173.88 \mathrm{a}$ & $1199.00 \mathrm{a}$ & $770.25 \mathrm{~b}$ & $67.37 \mathrm{c}$ & $800.28 \mathrm{~A}$ \\
\hline $20.14 \mathrm{~m}$ & $800.50 \mathrm{~b}$ & $1173.88 \mathrm{a}$ & $1186.88 \mathrm{a}$ & $750.75 \mathrm{~b}$ & $67.62 \mathrm{c}$ & $795.93 \mathrm{~A}$ \\
\hline $23.14 \mathrm{~m}$ & $793.63 \mathrm{~b}$ & $1166.75 \mathrm{a}$ & $1185.63 \mathrm{a}$ & $748.00 \mathrm{~b}$ & $68.37 \mathrm{c}$ & $792.48 \mathrm{~A}$ \\
\hline \multicolumn{7}{|c|}{ Site 2: Area between strips of trees } \\
\hline $2.66 \mathrm{~m}$ & $299.62 \mathrm{ab}$ & $595.25 \mathrm{a}$ & $557.00 \mathrm{a}$ & $382.87 \mathrm{a}$ & $29.62 \mathrm{~b}$ & $372.88 \mathrm{~B}$ \\
\hline $5.78 \mathrm{~m}$ & $761.00 \mathrm{a}$ & $1032.00 \mathrm{a}$ & $1061.38 \mathrm{a}$ & $416.88 \mathrm{~b}$ & $44.12 \mathrm{c}$ & $663.08 \mathrm{~A}$ \\
\hline $8.58 \mathrm{~m}$ & $791.88 \mathrm{a}$ & $1189.63 \mathrm{a}$ & $1195.38 \mathrm{a}$ & $332.13 \mathrm{~b}$ & $73.63 \mathrm{~b}$ & $716.53 \mathrm{~A}$ \\
\hline $\begin{array}{c}\text { Overall } \\
\text { Mean }\end{array}$ & $690.23 \mathrm{~b}$ & $1041.18 \mathrm{a}$ & $1054.82 \mathrm{a}$ & $550.52 \mathrm{c}$ & $57.19 \mathrm{~d}$ & \\
\hline
\end{tabular}

Means followed by the same lower case letter within a line or followed by the same uppercase letter within a column do not differ according to Tukey's test at the $5 \%$ significance level. Standard error $=24.3$. 

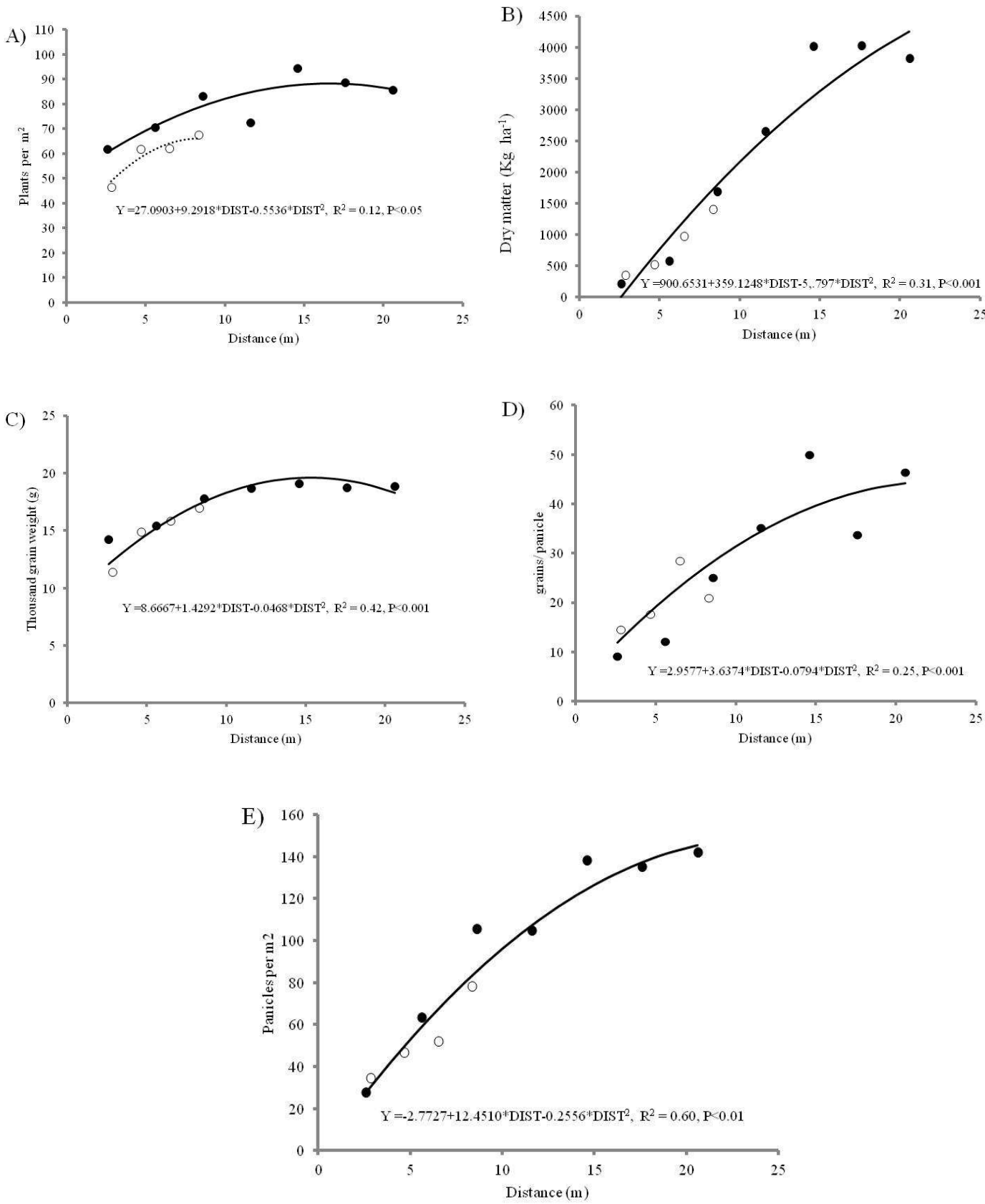

- Outside the tree strips OBetween the tree strips

Figure 4 - Relationships between distance between trees and (A) plants per $\mathrm{m}^{2}$, (B) dry matter, (C) thousand grain weight, (D) grains per panicle, and (E) panicles per unit area of a wheat crop grown in an agroforestry system in São Carlos, São Paulo state, Brazil.

Figura 4 - Relação entre plantas por $m^{2}$ (A), matéria seca (B), massa de 1000 grãos (C), número de grãos por panícula (D), panículas por unidade de área (E) da cultura de aveia e distância do renque de árvores de um sistema silviagricola em São Carlos, SP.

Revista Árvore, Viçosa-MG, v.40, n.3, p.509-518, 2016 
which the experiment was carried out did not include light levels capable of maximizing production.

Number of plants $/ \mathrm{m}^{2}$ (Figure 4A) varied with distance from trees for both sites $(\mathrm{P}<0.05)$. The equations differed at the two sites $(\mathrm{P}<0.01)$. At the site between the strips of trees, quadratic and linear regression trends for plants $/ \mathrm{m}^{2}$ were similar, indicating that equilibrium had not yet been reached. The competition caused by the proximity of trees led to lower levels of establishment of oat plants, and was also reflected in the fact that dry matter production increased with increasing distance from trees (Figure 4B), following a quadratic relationship. Dry matter production did not vary between sites $(\mathrm{P}>0.05)$.

There was no difference between sites in thousand grain weight, number of grains/panicle, and number of panicles $/ \mathrm{m}^{2}(\mathrm{P}>0.05$; Figures $4 \mathrm{C}, 4 \mathrm{D}, 4 \mathrm{E})$. Although there was no difference in the number of grains/panicle between sites, the data from the crops between the tree strips were scattered to an extent that they fit neither linear nor quadratic regressions $(\mathrm{P}>0.05)$. In all of the other cases, quadratic regression showed a better fit to the data. Thousand grain weight, the number of grains/panicle, and the number of panicles $/ \mathrm{m}^{2}$ increased $(\mathrm{P}<0.05)$ with increasing distance from trees.

\section{DISCUSSION}

PAR declined close to trees. The relationship between distance from trees and PAR availability showed that locations $\geq 10 \mathrm{~m}$ from trees received $>90 \%$ of the maximum radiation level observed. In an agroforestry system with rubber trees and a bean crop, Righi e Bernardes (2008) obtained fractions of radiation incidence $>90 \%$ starting at approximately $20 \mathrm{~m}$ from the nearest line of rubber trees ( $14 \mathrm{~m}$ tall), which illustrates the influence of the elements of an agroforestry system on the distribution of light.

Oat production was lower close to trees. Competition caused by the proximity of trees led to fewer oat plants establishing $(\mathrm{P}<0.05$, Figure $4 \mathrm{~A})$ and was also reflected in the dry matter production, which increased with increasing distance from the trees $(\mathrm{P}<0.05$, Figure 4B). In a similar study, maize cultivated between lines of 24-month old, 11-14 m tall eucalyptus trees spaced at $10 \times 4 \mathrm{~m}$ grew at a density that was $24-39 \%$ of that observed when it was grown alone (MACEDO et al., 2006). Oat crop density also increased significantly with increasing distance from trees in the 'dehesas' of Spain - associations of 20-60 trees/ha and an herbaceous layer (MORENO et al., 2007). In our study mean oat dry matter production varied from $214 \mathrm{~kg} /$ ha (between tree strips) to $357 \mathrm{~kg} / \mathrm{ha}$ (outside tree strips) in the first planted line (the one closest to the trees), where shade was deepest, and exceeded $4000 \mathrm{~kg} / \mathrm{ha}$ $14 \mathrm{~m}$ from the trees. Mean oat dry matter productivity varies from 2 to $6 \mathrm{t} / \mathrm{ha}$ (KICHEL; MIRANDA, 2000). While the values we observed for the lines with the highest PAR incidence fall within this range, production may have been compromised by the drought conditions during the experiment (Figure 2).

Growth of the oat crop may have also been compromised by changes in light quality caused by the nearby trees. Radiation filtered through tree canopies has a different spectrum, with a lower red:far red ratio due to the selective absorption by leaf pigments (MARTINEZ-GARCIA et al., 2010). Many plants respond to a lower red:far red ratio in incident light with increased apical dominance (SCHMITT; WULFF, 1993). Lower PAR also increases apical dominance (ALMEIDA; MUNDSTOCK, 2001), with the result that the light conditions in our study might have converged to reduce tillering. In addition to reducing the number of tillers, shading also reduces their dry matter production (ALMEIDA; MUNDSTOCK, 2001) and can reduce grain production. Grain production is affected by the number of fertile tillers, which in cereals depends on the environmental conditions between tiller initiation and flowering. Environmental stresses during the emergence of tillers can inhibit their formation and, in later stages, cause them to abort (MAAS et al., 1994). Various studies have demonstrated the negative effect of adult trees on the dry matter yield of associated crops, and this has been partly attributed to lower light availability. Barro et al. (2008) reported that a winter crop of black oats in Rio Grande do Sul, Brazil, grown with Pinus elliottii stands that intercepted $24 \%$ and $56 \%$ of incident light produced 25\% (2907 kg/ha) and 58\% $(1627 \mathrm{~kg} / \mathrm{ha})$, respectively, of crops grown in full sun. Kirchner et al. (2010) documented significant microclimatic changes in agroforestry systems with $P$. taeda in the wet subtropics, recording PAR interception in a stand spaced at $15 \times 3 \mathrm{~m}$ as $30 \%$ in June and 66\% in March-April. Under these conditions, the production of black oats was $1963 \mathrm{~kg} / \mathrm{ha}$, or $43 \%$ of that under full sun. Under higher mean levels of

Revista Árvore, Viçosa-MG, v.40, n.3, p.509-518, 2016

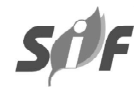


light interception (60\% and $83 \%)$ in a stand spaced at $9 \times 3 \mathrm{~m}$, dry matter production was just $369 \mathrm{~kg} /$ ha, comparable to that observed in our study in the lines closest to the trees. In our study, however, plants were also subjected to drought stress.

The proximity of trees may increase also the competition for water. About $90 \%$ of oats roots were found superficially, at soil depths up to $20 \mathrm{~cm}$ (SOUTO et al., 1992). In the present study soil humidity $(0-20 \mathrm{~cm})$ did not show differences among distances from the trees $(10.00 \% \pm 1.53 \%, \mathrm{P}>0.05)$. It is possible however that water content changed deeper in the soil, and the uptake by trees might have contributed to the increased stress of oats during the season.

Thousand grain weight, number of grains/panicle, and number of panicles $/ \mathrm{m}^{2}$ increased $(\mathrm{P}<0.05)$ with increasing distance from trees. There are several possible causes for the reduced development of oat grains, some of which have been discussed above. Since the final accumulation of mass of grains depends mostly on the availability of photosynthates (DIDONET et al., 2001), it is reasonable to suppose that the lower dry mass of grains grown close to trees is the result of lower photosynthetic rates in shade. In addition, after fructification, grains become favored 'sinks' for plants, which must invest in them heavily and constantly. When the photosynthetic rate is insufficient for satisfying those demands, reserves from the culm are needed to fill the grains. For that reason, the culm's capacity for storing excess photosynthate is critical for the period of grain filling (DIDONET etal., 2001; FANCELLI, 2003). Macedo et al. (2006) observed lower weight, lower quality (lower cob size and poorly-formed grains) of corn cobs and lower grain yield in systems grown together with eucalyptus trees than in monocultures, and attributed the result to competition for light.

In our study, we documented a relationship between low PAR and low production. There was a positive relationship between proportional PAR incidence and aboveground biomass production ( $\mathrm{P}<0.05$, Figure 3 ), even though the light levels that maximize production were not reached. This contrasts with the results of Semchenko e Zobel (2005), who reported a plateau of black oat production at 50\% incident light. Although PAR was similar between 5,14 m, 8,14 $\mathrm{m}$ and 23,14 m considering the whole evaluation, at 14:45 PAR incidence was just $52 \%$ and $63 \%$ for $5,14 \mathrm{~m}$ and $8,14 \mathrm{~m}$, respectively, compared to $23,14 \mathrm{~m}$.
Our dataset indicates that pruning did not satisfactorily reduce competition for light. Competition still prevailed, considering that dry matter production of oats increased with increasing distance from trees, following a quadratic relationship. Studies have reported significant reductions in light interception after partial pruning (JACKSON et al., 2000; BAYALA et al., 2002), as well as reductions in evapotranspiration (BAYALA et al., 2002) and root mass (PETER; LEHMANN, 2000) after pruning in agroforestry systems. While these changes may reduce competition for light, water, and nutrients between trees and crops in the understory, it was not enough to reestablish crop productivity in this study. Competition increased from the 2010 rainy season to the 2011 dry season. This study with a production system based on native timber species with monopodial (mutambo) and sympodial (capixingui) growth forms suggests that pruning cannot be recommended with the only purpose of increasing light availability or for reducing competition between trees and agricultural crops. Pruning, at least with the criteria we adopted, was not capable of reverting competition, bringing back productivity to acceptable limits, comparable to conditions where competition was less evident (at $23 \mathrm{~m}$ from trees, for example). Other option, would be felling part of the trees. The removal of part of the trees reduces competition. The challenge is defining the minimal number of trees to be felled to reestablish crop production to acceptable levels.

\section{CONCLUSIONS}

1. Pruning was not effective at reducing competition between tree and crop in the system composed of native species exhibiting both sympodial and monopodial type of growth.

2. While it is not possible to exclude the role of other factors in the productivity of black oats, the shading they experienced because of nearby trees plays a key role in the competition observed.

\section{ACKNOWLEDGMENTS}

This research work was financially supported by Embrapa-Empresa Brasileira de Pesquisa Agropecuária. We are thankful for the scholarship granted to Paula Priscila Castiglioni by CNPq - Conselho Nacional de Desenvolvimento Científico e Tecnológico. We thank Cristiam Bosi, Talitha Kirchner, Bernard Felipe Batista, 
and the other grantees for their help collecting samples; Dr. Francisco H. D. de Souza and Natal Sylvestre for help examining black oat seeds; Dr. Gustavo Maia Souza for advice; and Pedro Gomes da Cruz for help with the analyses.

\section{REFERENCES}

ALMEIDA, M.L.; MUNDSTOCK, C.M. O afilhamento da aveia afetado pela qualidade da luz em plantas sob competição. Ciência Rural, v.31, n.3, p.393-400, 2001.

BALBINO, L.C.; BARCELLOS, A.O.; STONE, L.F. (Eds.). Marco referencial integração lavoura-pecuária-floresta. Brasília: Embrapa, 2011. 130p.

BARRO, R. S.; SAIBRO, J. C. D.; MEDEIROS, R. B. D.; SILVA, J. L. S. D.; VARELLA, A. C. Rendimento de forragem e valor nutritivo de gramíneas anuais de estação fria submetidas a sombreamento por Pinis elliottii e ao sol pleno. Revista Brasileira de Zootecnia, v.37, n. 10, p.1721-1727, 2008.

BAYALA, J.; TEKLEHAIMANOT, Z.; QUEDRAOGO, S.J. Millet production under pruned tree crowns in parkland system in Burkina faso. Agroforestry Systems, v.54, p.203-214, 2002

CARPANEZZI, A.A.; NEVES, E.J.M.; AGUIAR, A.V.; SOUSA, V.A. Espécies lenhosas alternativas para fins econômicos no Paraná. II Seminário de atualização florestal e XI Semana de Estudos Florestais. Embrapa Florestas, 2010, Colombo - PR. Anais... 2010 [2010]. [Acesso em 10 nov. 2010] .Disponível em: http:// anais.unicentro.br/sef2010/pdf/palestras/ Carpanezzi.pdf.

DIDONET, A.D. et al. Crescimento e desenvolvimento de milho: acúmulo de massa seca do grão. Pesquisa Agropecuária Brasileira, v.36, n.3, p.447-456, 2001.

EMPRESA BRASILEIRA DE PESQUISA AGROPECUÁRIA - EMBRAPA. Sistema brasileiro de classificação de solos. Brasília: SPI, 1999.

ENCINAS, J.I.; SILVA, G.F.; PINTO, J.R.R. Idade e crescimento das árvores. Comunicações
Técnicas Florestais, v.7, n.1, dez. 2005.

FANCELLI, A.L. Fisiologia, nutrição e adubação do milho para alto rendimento. In: POTAFOS Brasil Presentations. [2003] [acesso em 03 abr. 2011. Disponível em: http://www.google.com.br/ url? $\mathrm{sa}=\mathrm{t} \& \mathrm{rct}=\mathrm{j} \& \mathrm{q}=$ FISIOLOGI A $\% 2 \mathrm{C}+\mathrm{NUTRI} \% \mathrm{C} 3 \% 87 \% \mathrm{C} 3 \% 83 \mathrm{O}+$ E+ADUBA $\% \mathrm{C} 3 \% 87 \% \mathrm{C} 3 \% 83 \mathrm{O}+1+\mathrm{DO}+\mathrm{MILHO}+\mathrm{PARA}+$ ALTO+RENDIMENTO\&source $=$ web\&cd $=1 \&$ ved $=0$ CEAQFjAA\&url $=\mathrm{http} \% 3 \mathrm{~A} \% 2 \mathrm{~F}$ $\% 2$ Fwww.ipni.net $\% 2$ Fppiweb\%2Fpbrazil.nsf $\%$ 2F1c678d0ba742019483256e19004af5b8\%2F7ac8 $77864218 \mathrm{~d} 46983256 \mathrm{c} 70005790 \mathrm{fc} \% 2 \mathrm{~F} \% 24 \mathrm{FILE} \% 2 \mathrm{FAnais}$ $\% 2520$ Antonio\%2520Luiz\%2520Fancelli.doc\& ei $=$ d7V8T9nTLMn2ggfih7TTDw\&usg $=\mathrm{AFQjCNG} 94$ peUvk2d9BF-d_fkjtE_yayJbA.

JACKSON, N.A.; WALLACE, J.S.; ONG, C.K. Tree pruning as a mean of controlling water use in an agroforestry system in Kenia. Forest Ecology and Management, v.126, p.133148,2000

JOSE, S.; GILLESPIE, A.R.; PALLARDY, S.G. Interspecific interactions in temperate agroforestry. Agroforestry Systems, v.61-62, n.1, p.237-255.2004

KICHEL, A.N.; MIRANDA, C.H.B. Uso da aveia como planta forrageira. Campo Grande: Embrapa Gado de Corte, 2000.5 p. (Gado de Corte Divulga, 45).

KIRCHNER, R.; SOARES, A.B.; SARTOR, L.R.; ADAMI, P.F.; MIGLIORINI, F.; FONSECA, L. Desempenho de forrageiras hibernais sob distintos níveis de luminosidade. Revista Brasileira de Zootecnia, v.39, n.11, p.23712379, 2010.

MAAS, E. V.; LESCH, S. M.; FRANCOIS, L. E.; GRIEVE, C. M. Tiller development in saltstressed wheat. Crop science, v. 34, n. 6 , p. 1594-1603, 1994.

MACEDO, R.L.G.; BEZERRA, R.G.; VENTURIN, N.; VALE, R.S.; OLIVEIRA, T.K. Desempenho silvicultural de clones de eucalipto e características agronômicas de milho cultivados em sistema silviagrícola. Revista Arvore, v.30, n.5, p.701-709, 2006

Revista Árvore, Viçosa-MG, v.40, n.3, p.509-518, 2016

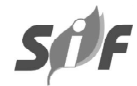


MARTINEZ-GRACIA, J.F.; GALSTYAN, A.; SALLA-MARTRET, M.; CIFUENTES-ESQUIVEL, N.; GALLEMÍ, M.; BOU-TORRENT, J. Regulatory components of shade avoidance syndrome. Advances in Botanical Research, v.53, p. 65-116, 2010.

MORENO, G.; OBRADOR, J.J.; GARCÍA, A. Impact of evergreen oaks on soil fertility and crop production in intercropped dehesas.

Agriculture, Ecosystems and

Environment, v.119, p.270-280, 2007.

PETER, I.; LEHMANN, J. Pruning effects on root distribution and nutrient dynamics in an acacia hedgerow planting in northern Kenya. Agroforestry Systems, v.80, p.59-75, 2000.

RIBASKI, S.J.; MONTOYA, L.J.; RODIGHERI, H.R. Sistemas Agroflorestais: aspectos ambientais e sócio-econômicos. [acesso em 16 maio. 2006]. Disponível em: http:// www.planetaorganico.com.br/TrabRibaski.htm.

RIGHI, C.A.; BERNARDES, M.S. Disponibilidade de energia radiante em um sistema agroflorestal com seringueiras: produtividade do feijoeiro.
Bragantia, v.67, n.2, p.533-540, 2008.

RUSCHEL, A.R.; NODARI, E.S.; GUERRA, M.P.; NODARI, R.O. Evolução do uso e valorização das espécies madeiráveis da Floresta estacional decidual do Alto-Uruguai, SC. Ciência Florestal, v.13, n.1, p.153-166, 2003.

SCHMITT, J.; WULFF, R.D. Light spectral quality, phytochrome and plant competition. Trends in Ecology \& Evolution, v.8, n.2, p.47-51, 1993.

SEMCHENKO, M.; ZOBEL, K. The effect of breeding on allometry and phenotypic plasticity in four varieties of oat (Avena sativa L.). Field Crops Research, v.93, p.151-168, 2005.

SOUTO, J.S.; ISHY, T.; ROSOLEM, C.A.; CAVARIAN, C. Distribuição do sistema radicular da aveia preta em função da população e espaçamento. Pesquisa Agropecuária Brasileira, v.27, p.1283-1289, 1992.

THORNTHWAITE, C.W.; MATHER, J.R. The water balance. New Jersey: Drexel Institute of Technology, 1955. 104p. 